\title{
ECONOMIC EXPECTATIONS OF TURKISH YOUTH FROM EU MEMBERSHIP*
}

\author{
Efehan DANIŞMAN ${ }^{* *}$ \\ İmre ERSOY ${ }^{* * *}$
}

\begin{abstract}
This paper analyses young people's perception of the European Union (EU), their expectations from the EU membership and particularly economic expectations of the youth from the EU membership. The study has been conducted with 485 samples through internet and face to face interviews in Istanbul. Attendees are asked 17 different questions concerning their age, gender, income, where they were born, EU's image, belief in EU membership, economic expectations from the EU membership and university students' prospects to go and live in the EU countries. The analysis finds that university students have rather neutral EU image and do not see EU as source of prosperity as before. Most of them do not believe that Turkey will ever be an EU member. Nonetheless, university students would like to go and live in the EU countries.
\end{abstract}

Keywords: European Union, public opinion, EU Economics

\section{TÜRK GENLIĞİNIN AVRUPA BİRLİĞİ ÜYELIĞİNDEN EKNOMIKK BEKLENTILERI}

\section{Özet}

Bu makale gençlerin Avrupa Birliği’ne(AB) baklşlarını, AB üyeliğinden beklentilerini, özellikle de ekonomik beklentilerini analiz etmektedir. Çalışma Istanbul'daki 485 örneklemle internet ve yüz yüze görüşmelerle 17 soruluk bir anketin katılımcılara yöneltilmesiyle gerçekleştirilmiştir. Sorular katılımcıların yaşı, cinsiyeti, geliri, doğduğu şehir, AB’nin imajl, AB üyeliğine olan inancı, $A B$ 'den ekonomik beklentileri ve AB ülkelerinde yaşama ve çalışma isteğini ölçmeyi amaçlamıştır. Sonuçlara göre gençler artık AB'yi eskisi gibi bir refah kaynă̆ olarak görmemekte ve AB'nin imajını nötr olarak görmektedirler. Üniversite

\footnotetext{
* This article is the revised version of the MA thesis submitted to the European Union Institute of Marmara University in 2013

$* *$

MA, Marmara University, European Union Institute, Department of EU Economics, email:efehandanisman@yahoo.com

*** Asst. Prof. (PhD), Marmara University, European Union Institute, Department of EU Economics, email: iersoy@marmara.edu.tr
} 
öğrencilerinin büyük bölümü Türkiye'nin hiçbir zaman AB'ye üye olamayacağına inanmaktadır. Bunun yanında katılımcıların büyük bölümü AB ülkelerinde yaşamak ve çallşmak istemektedir.

Anahtar kelimeler: Avrupa Birliği, kamuoyu yoklaması, AB İktisadı

\section{Introduction}

Turkey and the EU have a long-standing relationship with many ups and downs throughout the history. This paper looks for a relatively less studied area of the Turkey - EU Relations by analyzing young Turkish people's general and economic expectations from the EU and their perceptions of the EU.

To reach this aim a survey with 17 questions has been conducted with 485 university students. The survey tried to look for demographic aspects of the university students such as gender, age, region where he/she was born, monthly income and study field. Afterwards, the survey tried to analyze subjective and objective knowledge level of the university students, EU's image, belief in Turkey's EU membership, their economic expectations from the EU and tendency to work and live in the EU countries.

First of all, lack of studies in this area especially on young people is an important short-coming since public opinion is becoming more important day by day. Turkey's young population is also an important determinant since half of Turkey is under 29 years of age. It is argued by many scholars that young people are considered as Turkey's greatest asset if they can be well educated. But there is one question when it comes to Turkey's relationship with the EU. Do young people still perceive EU as source of economic prosperity? Do they still want to live and work in EU countries? In case of an accession or not, the paper aimed to look for whether university students from Istanbul have still economic expectation from the EU or whether they would like to go and live in European countries in search of prosperity.

According to previous surveys by different scholars or institutions such as Eurobarometer and German Marshall Fund Transatlantic Trends, support to the Turkey's EU accession and integration is diminishing. This is an important concern since EU membership should be a grass-root project rather than a mere political one in Turkey to be completed successfully. Furthermore, even at the Eurobarometer surveys age distributions of attendants are not clearly presented.

In all Eurobarometer surveys, Turkish people have lowest level of knowledge concerning the EU affairs compared to other EU member states. Our survey looked for objective and subjective knowledge level of the university students as well. 
This paper has chosen university students in Istanbul as target group due to practicality and lack of studies exclusively for the university students. The rest of the paper is organized as follows: Section 2 reviews the literature concerning previous surveys conducted on Turkish people's public opinion about the EU. Section 3 explains data and methodology of the survey. Section 4 reveals main findings of the survey and hypothesis testing and discusses the empirical findings. Finally section 5 concludes

\section{Literature Review}

When one looks at the studies concerning Turkish public opinion on Turkey's EU membership and the EU in general, it can be seen that most systematic studies are done by Eurobarometer which started after Turkey became an official candidate in 1999. Beforehand there were a few studies which were conducted irregularly with limited sample.

First years of those systematic studies showed that the support to the EU membership were at peak levels. Yet support started to decrease each year afterwards. Support level to the EU membership decreased from $74 \%$ to $41 \%$ in 12 years (Eurobarometer, 1999-2011). This trend can also be seen at the German Marshall Fund's Transatlantic Trends Survey (2004-2012) and Turkstat's (2011) survey on the youth. Graph 1 shows diminishing support to the EU membership in Turkey according to Eurobarometer surveys.

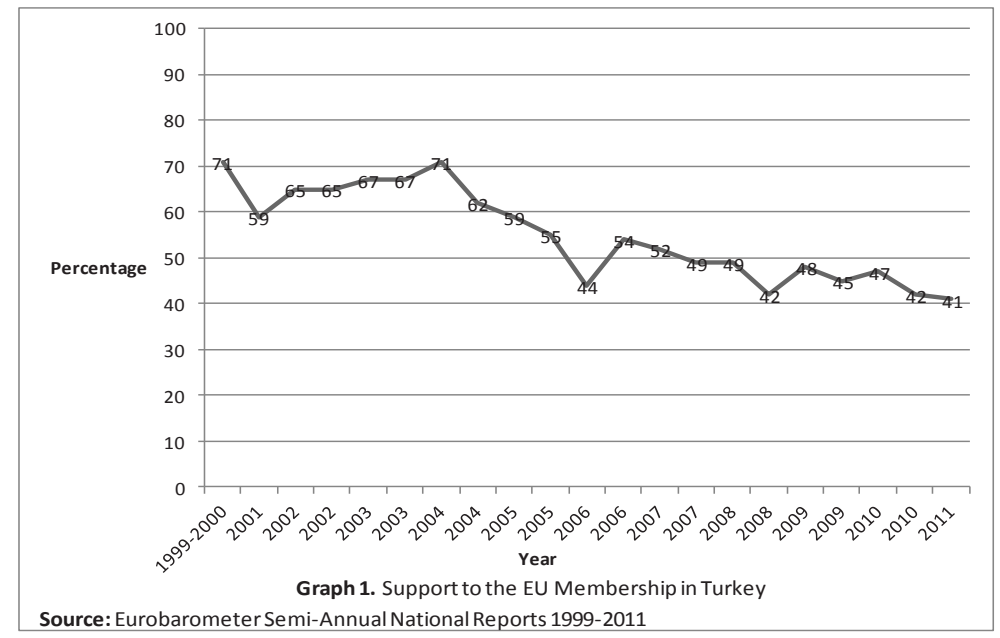

When people were asked about what EU meant for them, answer has always been prosperity until recent years. Nevertheless starting from 2012, for the first time economic prosperity lost its first rank among public's expectations from the EU 
membership. Rather freedom to travel, study and work took its place. Economic prosperity decreased from 50\% to 20\%'s between 2004 and 2012. Other researches such as Kadir Has University (2011, 2012, 2013), Yilmaz (2005) and Dartan, M., Nas, C., Akman, S. Savran, C. and Suner, S., (2004) also support this evidence. Graph 2 shows change in the meaning of the EU membership for the public in Turkey.

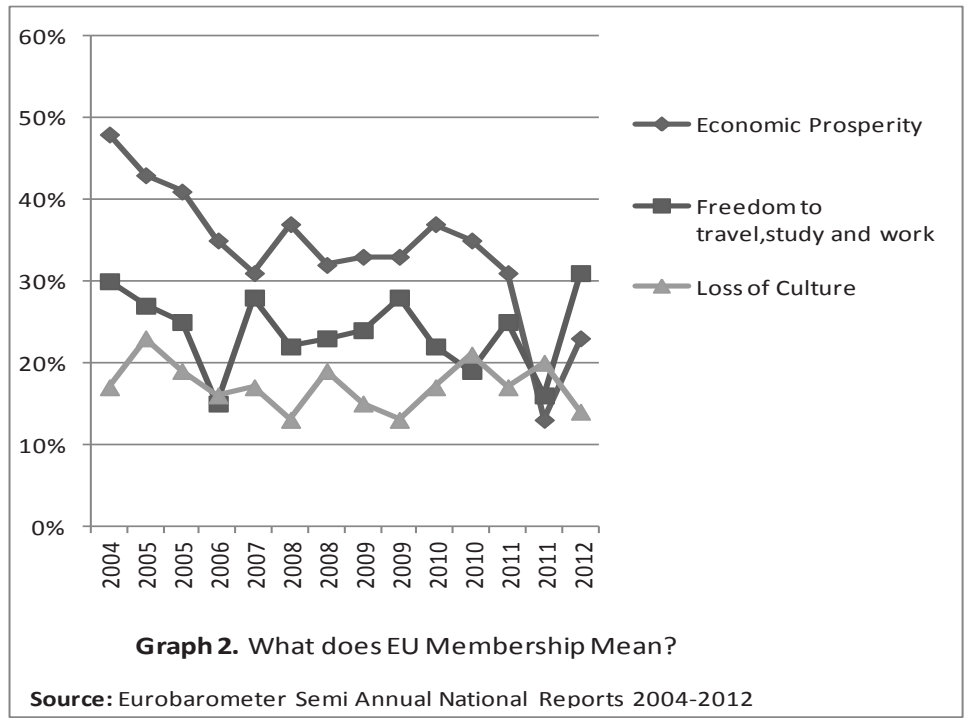

Studies which exclusively analyze youth's public opinion are important. Turkish Social Sciences Association (2005) made a survey with 4200 high school students in $2005.66 .9 \%$ of the high school students see EU as a positive thing while only $18.6 \%$ perceive it negatively. It is important to note that 2005 is the year when support to the EU membership was at peak.

Turkstat (2011) also looked for youth's public opinion on different issues between 2005 and 2011. Voting yes to the EU membership in a possible referendum is showing declining trend from $74 \%$ to $47.2 \%$ between those years. Graph 3 shows this declining trend. 


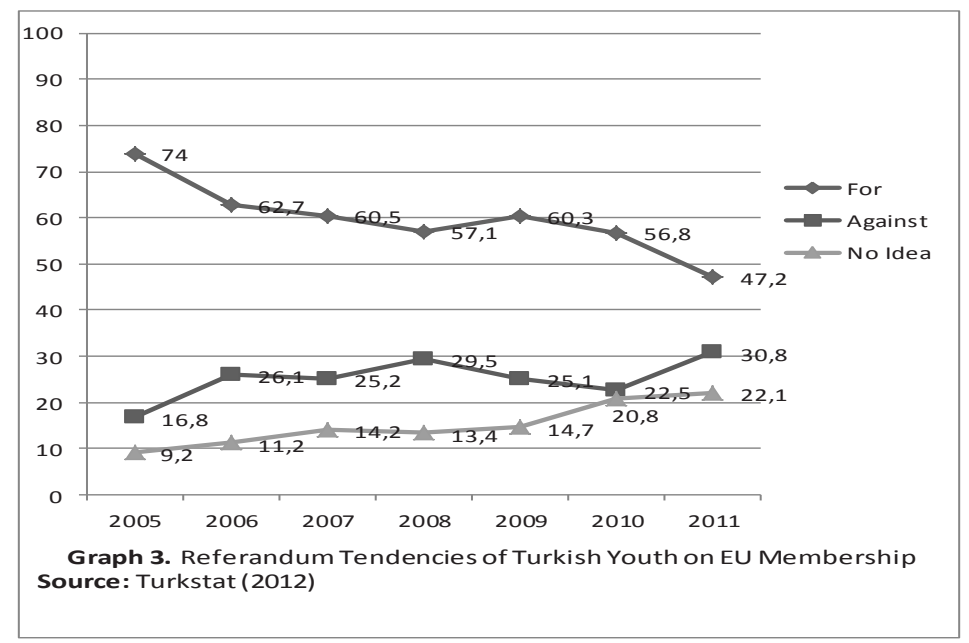

For the public opinion of the youth, Marmara University's study is worth considering as well. Study has been conducted by a group of scholars from the European Union Institute of the Marmara University with 886 students of the university. According to this study $46.7 \%$ perceives EU's image positive while $24.6 \%$ are neutral and $15.7 \%$ are negative. $68 \%$ of the students would vote yes to EU membership in a referendum while only $21 \%$ opposes (Dartan, M., Nas, C., Akman, S. Savran, C. and Suner, S., 2004).

When current studies concerning Turkish public's attitude are analyzed, it can be seen that support to the Turkey's EU membership diminished. EDAM (2013) conducted a study with 1500 people and $33.3 \%$ of the attendants stated that Turkey should insist on full membership to the EU while 19\% stated that Turkey should give up EU membership. Study conducted by Kadir Has University (2013) reveals that support to the EU membership is $50 \%$ in 2012 which is slightly higher than other studies.

Lack of studies exclusively for university students, lack of access to the age distributions of each question at Eurobarometer and Transatlantic Trends Survey and the question concerning whether young people still see EU as a source of prosperity are the main motivations of this paper.

\section{Survey and Data}

This paper aimed to analyze the relationship between demographic features and university students' economic expectations from the EU, EU image, tendency to vote in a possible referendum, belief in Turkey's EU membership, tendency to go 
and live in the EU countries and knowledge level. For this reason a survey is conducted with 485 university students in Istanbul.

Youth's public opinion is more important in Turkey's case since $25 \%$ of the population is considered young with 18.848 .407 people according to Turkstat (2011). This paper considers ages between 18 and 29 as young just like the way EU defines. Population of this paper is university students in Istanbul. Turkish Student Selection and Placement Center (OSYM) 2011-2012 Higher Education Statistics states that there are 4.353.542 students in higher education in Turkey including distant education (OSYM, 2012). 401.780 of them are studying in one of the 42 universities of Istanbul according to the same document which constitutes population of this paper (OSYM, 2012). When population is over 100.000, acceptable number of sample in a survey is 384 with $95 \%$ confidence level (Triola, 2010). Sample of this survey is slightly more than $0.1 \%$ of the whole university students in Istanbul with 485 attendants. Random sampling is used while selecting samples. Survey is conducted through mostly internet.

Cross-sectional survey is conducted to get perceptions at one point of time from the university students in Istanbul. Questions are either taken or inspired from surveys such as Eurobarometer and The German Marshall Fund Transatlantic Trends.

Survey has 17 questions. First 5 questions aimed to determine demographic specifications of the students such as gender, age, region where he/she was born, income and department which he/she studies. $6^{\text {th }}, 7^{\text {th }}$ and $8^{\text {th }}$ questions aimed to see students' objective and subjective knowledge level regarding the EU. 9th, 10th, $11^{\text {th }}$ and $12^{\text {th }}$ questions aimed to look for support level to the EU membership and university students' belief in EU membership.

$13^{\text {th }}, 14^{\text {th }}$ and $15^{\text {th }}$ questions are about the economic expectations which are the base of the paper. $16^{\text {th }}$ and $17^{\text {th }}$ questions are about young people's aspirations to work and study in the EU. Likert scale is used for $9^{\text {th }}, 13^{\text {th }}, 14^{\text {th }}, 15^{\text {th }}, 16^{\text {th }}$ and $17^{\text {th }}$ questions ${ }^{1}$.

Chi-square test is conducted to check if there is a relationship between two categorical variables. In our case the paper looks for a relationship between demographic features, support to the EU, tendency to go and live in the EU, knowledge level and economic expectations.

\footnotetext{
${ }^{1}$ Likert scale is a psychometric scale, one of the most common methods in researches, developed by Rensis Likert (Likert, 1932).
} 
21 hypotheses are constructed to analyse relationship between different variables. Also, the paper will present main findings of the 17 questions. Table-1 shows distribution of the demographic features of the attendants.

Attendants have mostly middle income since more than $75 \%$ of them have between 1000TL and 5000TL monthly income.

Almost $60 \%$ of the university students in Istanbul were born in Marmara region. Respectively other regions where university students were born are Central Anatolia (11.55\%), Aegean (7.22\%), Mediterranean (7.22\%), Black Sea (7.01\%), East Anatolia (4.74\%) and Southeast Anatolia (2.89\%). 
Table 1: Demographic Features of the Attendants

\begin{tabular}{|c|c|c|}
\hline Age & Frequency & Percentage \\
\hline $18-24$ & 373 & $76.91 \%$ \\
\hline $25-29$ & 112 & $23.09 \%$ \\
\hline Total & 485 & $100 \%$ \\
\hline Department he/she studies & Frequency & Percentage \\
\hline Social Sciences & 272 & $54,43 \%$ \\
\hline Engineering and Natural Sciences & 157 & $32,36 \%$ \\
\hline Fine Arts & 18 & $3,73 \%$ \\
\hline Medicine and Health Sciences & 9 & $1,85 \%$ \\
\hline Literature and Linguistics & 17 & $3,50 \%$ \\
\hline Other & 14 & $2,89 \%$ \\
\hline Don't want to answer & 6 & $1,24 \%$ \\
\hline Total & 485 & $100 \%$ \\
\hline Income & Frequency & Percentage \\
\hline Under 1000TL & 51 & $10.52 \%$ \\
\hline $1000-2500 \mathrm{TL}$ & 227 & $46.80 \%$ \\
\hline $2500-5000 \mathrm{TL}$ & 146 & $30.10 \%$ \\
\hline Over $5000 \mathrm{TL}$ & 61 & $12.58 \%$ \\
\hline Total & 485 & $100 \%$ \\
\hline Gender & Frequency & Percentage \\
\hline Male & 221 & $45.57 \%$ \\
\hline Female & 264 & $54.43 \%$ \\
\hline Total & 485 & $100 \%$ \\
\hline Region he/she was born & Frequency & Percentage \\
\hline Aegean & 35 & $7.22 \%$ \\
\hline Blacksea & 34 & $7.01 \%$ \\
\hline Central Anatolia & 56 & $11.55 \%$ \\
\hline East Anatolia & 23 & $4.74 \%$ \\
\hline Marmara & 288 & $59.38 \%$ \\
\hline Mediterranean & 35 & $7.22 \%$ \\
\hline Southeast Anatolia & 14 & $2.89 \%$ \\
\hline Total & 485 & $100 \%$ \\
\hline
\end{tabular}


When attendants' subjective and objective knowledge levels concerning the EU are tested by the survey, the results are quite different than previous surveys. In the past, knowledge level of the Turkish public has always been lowest vis-a-vis other EU member states. Nevertheless $53.72 \%$ of the attendants think that they know how EU functions. When one looks at the objective knowledge level, more than $70 \%$ of the attendants answered statements correctly which state "EU has 28 members with Croatia's accession" and "Switzerland is an EU member". This is clearly higher than general public's knowledge level which is measured in previous surveys.

Table 2: Subjective and Objective Knowledge Level of the Attendants

\begin{tabular}{|c|c|c|c|}
\hline \multicolumn{3}{|c|}{ I know functioning of the EU (decision-making, structure etc.) } \\
\hline \multicolumn{3}{|c|}{ Percentage } & \multicolumn{2}{c|}{ Frequency } \\
\hline Yes & No & Yes & No \\
\hline $53,81 \%$ & $46.19 \%$ & 261 & 224 \\
\hline \multicolumn{3}{|c|}{ EU will have 28 members with Croatia's Accession } \\
\hline \multicolumn{3}{|c|}{ Percentage } & Frequency \\
\hline Yes & No & 361 & No \\
\hline $74.43 \%$ & $25.57 \%$ & Frequency \\
\hline \multicolumn{4}{|c|}{ Switzerland is an EU Member } \\
\hline Percentage \\
\hline $27.84 \%$ \\
\hline
\end{tabular}

When young people are asked about the image of the EU, $47.22 \%$ of them chose neither positive nor negative as an answer. $27.84 \%$ of attendants have chosen positive while $15.46 \%$ of them have chosen negative. Only a tiny proportion, $3.92 \%$ and $5.57 \%$ sees it totally positive and totally negative respectively. Even though neutral answers are the majority, positive EU perception is still higher than negative. $47.22 \%$ will be important in terms of its distribution through positive or negative perception in the future. Graph 4 shows EU's image among university students in Istanbul. 


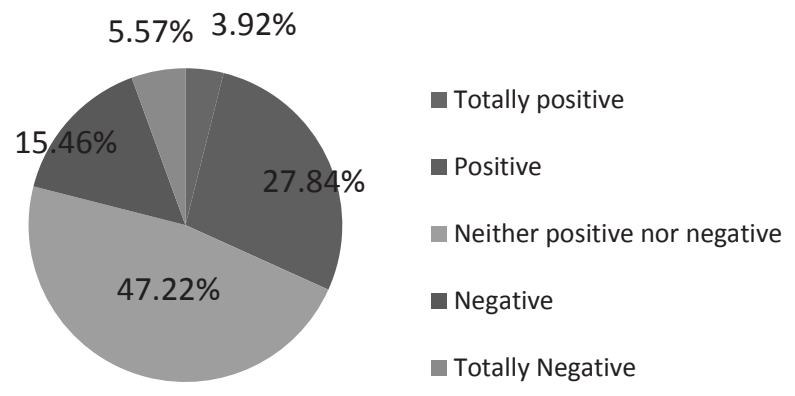

Graph 4. EU's Image Among University Students

University students are also asked whether EU membership is a good or bad thing. $42.27 \%$ perceives EU as a good thing while $29.28 \%$ responds negative. This question supported the argument that young people still perceive EU membership beneficial for Turkey even though a significant number of them perceive EU negatively or neutrally. Furthermore $56.08 \%$ of the attendants would vote yes in a referendum for Turkey's EU membership while $35.67 \%$ would vote no. Graph 5 shows whether university students see EU membership as a good thing or not.

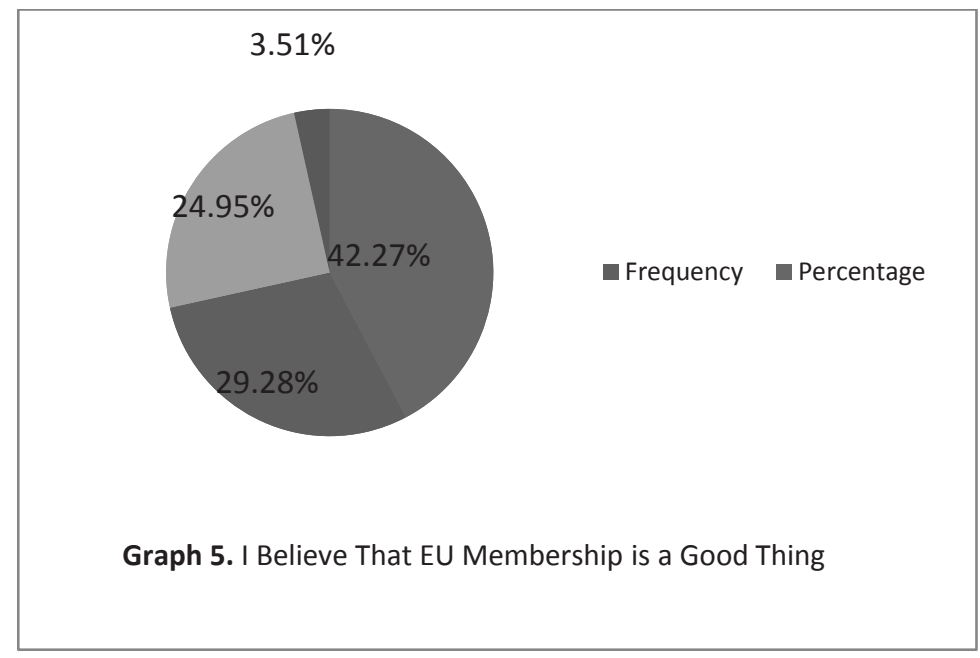


University students in İstanbul do not believe that Turkey will be an EU member according to results of our survey. $58.56 \%$ of them think that Turkey will never be an EU member while only $28.25 \%$ of them think that Turkey will be an EU member.

When it comes to economic expectations of the youth, $28.87 \%$ of the attendants think that Turkey's welfare will increase if Turkey will be an EU member. A small majority of the attendants with $29.28 \%$ disagreed with this statement while $27.63 \%$ of them chose to be neutral. $9.69 \%$ totally agreed while $4.54 \%$ totally disagreed. Graph 6 shows attendants' answers to the statement "If Turkey will be an EU member, Turkey's welfare will increase".

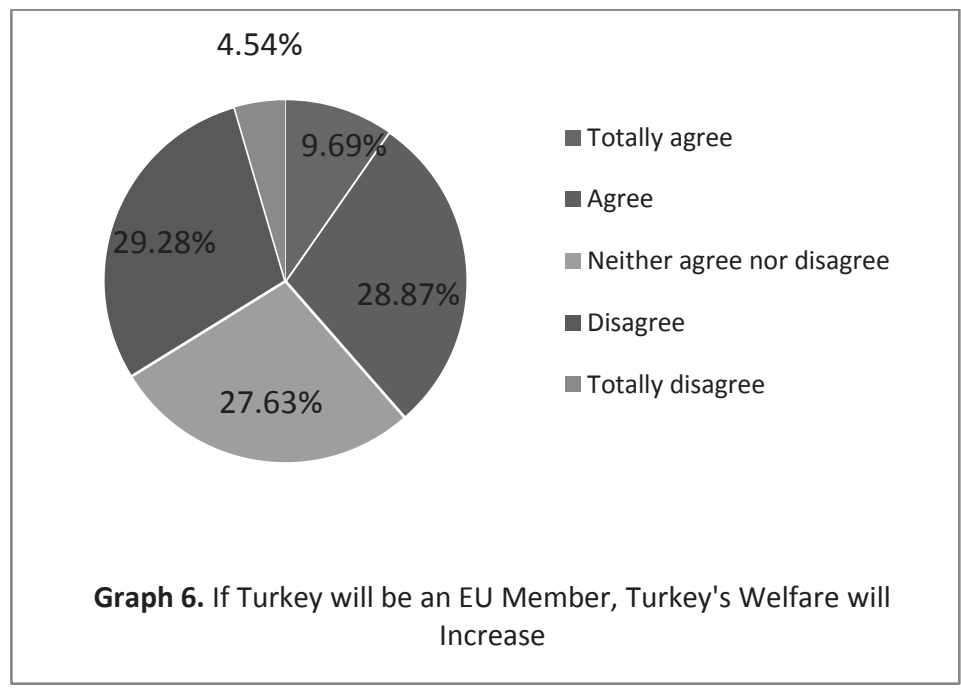

Concerning economic expectations, this time the statement was "EU means welfare for me". $29.69 \%$ of the attendants have chosen disagree as answer while $26.19 \%$ of them have chosen agree. Neither agree nor disagree option is selected by $26.80 \%$ of the attendants. $7.22 \%$ of them totally agree while $10.10 \%$ attendants totally disagree. Graph 7 shows university students' answer to the statement "EU means welfare for me". 


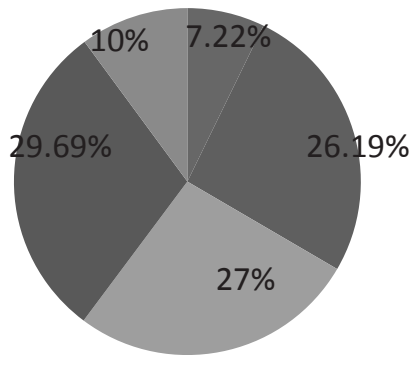

- Totally agree

Agree

Neither agree nor

disagree

Disagree

- Totally disagree

Graph 7. EU Means Welfare for me

Last statement is "EU means employment for me". 34.16\% of attendants agree while $24.64 \%$ of them disagree. $29.19 \%$ neither agree nor disagree while $8.07 \%$ and $3.93 \%$ of them totally agree and disagree respectively. There is a rather balanced result on university students' economic expectations from the EU.

In the last part of the survey, university students' tendency to go and live in the EU countries is asked with two statements. First one is "I would like to study in EU countries during next few years" while second is "I would like to live and work in EU countries during next few years". In the results of the first statement, it can be seen that young people would like to be in EU countries. $42.27 \%$ stated that they totally agree with first statement while $40.41 \%$ of them agree. Only $8.66 \%$ of university students are neutral and $6.39 \%$ disagree while $2.27 \%$ of them totally disagree. Graph 5 shows university students" answer to the statement "I would like to study in EU countries during next years". 


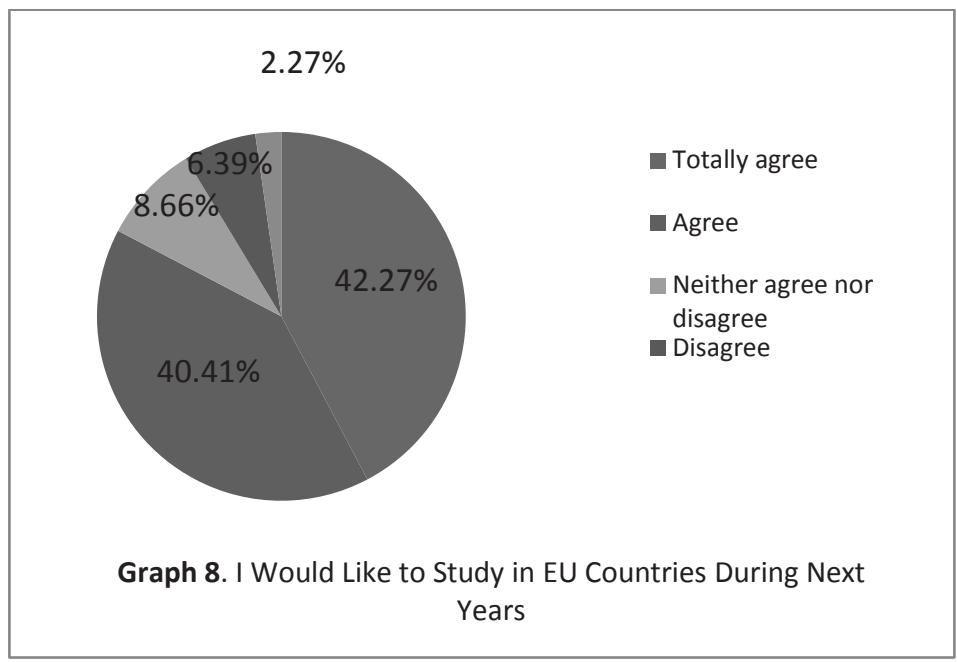

After presenting main findings of the survey, this part is going to present results of the hypothesis testing. Here there are 21 hypotheses constructed to analyze relationship between demographic features and university students' economic expectations from the EU, EU image, tendency to vote in a possible referendum, belief in Turkey's EU membership, tendency to go and live in the EU countries and knowledge level.

$\mathrm{H}_{0} 1$ : University students' subjective knowledge level and their perception on Turkey's welfare in case of EU membership have no relationship.

$\mathrm{H}_{1} 1$ : University students' subjective knowledge level and their perception on Turkey's welfare in case of EU membership have a relationship.

$\mathrm{H}_{0} 2$ : University students' income and their perception on Turkey's welfare in case of EU membership have no relationship.

$\mathrm{H}_{1} 2$ : University students' income and their perception on Turkey's welfare in case of EU membership have a relationship.

$\mathrm{H}_{0} 3$ : University students' EU image and their perception on Turkey's welfare in case of EU membership have no relationship.

$\mathrm{H}_{1} 3$ : University students' EU image and their perception on Turkey's welfare in case of EU membership have a relationship.

$\mathrm{H}_{0} 4$ : University students' region where he/she was born and their perception on Turkey's welfare in case of EU membership have no relationship. 
$\mathrm{H}_{1}$ 4: University students' region where he/she was born and their perception on Turkey's welfare in case of EU membership have a relationship.

$\mathrm{H}_{0}$ 5: University students' belief in Turkish accession to EU and their perception on Turkey's welfare in case of EU membership have no relationship.

$\mathrm{H}_{1}$ 5: University students' belief in Turkish accession to EU and their perception on Turkey's welfare in case of EU membership have a relationship.

$\mathrm{H6}_{0}$ : University students tendency to vote yes in a possible referendum and their perception on Turkey's welfare in case of EU membership have no relationship.

$\mathrm{H6}_{1}$ : University students tendency to vote yes in a possible referendum and their perception on Turkey's welfare in case of EU membership have a relationship.

$\mathrm{H}_{0}$ 7: University students' income and perception on their own welfare in case of EU membership have no relationship.

$\mathrm{H}_{1} 7$. University students' income and perception on their own welfare in case of EU membership have a relationship.

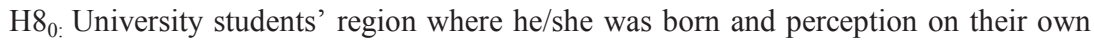
welfare in case of EU membership have no relationship.

H8 1 : University students' region where he/she was born and perception on their own welfare in case of EU membership have a relationship.

$\mathrm{H}_{0}$ 9: University students' tendencies to vote yes in a possible referendum and perception on their own welfare in case of EU membership have no relationship.

$\mathrm{H}_{0}$ 9: University students' tendencies to vote yes in a possible referendum and perception on their own welfare in case of EU membership have no relationship.

$\mathrm{H}_{0} 10$ : University students tendency to live and work in EU countries and perception on their own welfare in case of EU membership have no relationship.

$\mathrm{H}_{1} 10$ : University students tendency to live and work in EU countries and perception on their own welfare in case of EU membership have a relationship.

$\mathrm{H}_{0} 11$ : University students' income level and their EU image have no relationship.

$\mathrm{H}_{1}$ 11: University students' income level and their EU image have a relationship.

$\mathrm{H}_{0} 12$ : University students' income level and their tendency to vote yes in a possible referendum have no relationship.

$\mathrm{H}_{1} 12$ : University students' income level and their tendency to vote yes in a possible referendum have a relationship.

$\mathrm{H}_{0} 13$ : University students' income level and their belief in Turkey's EU accession have no relationship.

$\mathrm{H}_{1}$ 13: University students' income level and their belief in Turkey's EU accession have a relationship. 
$\mathrm{H}_{0} 14$ : University students' income level and their tendency to go and live in the EU countries have no relationship.

$\mathrm{H}_{1} 14$ : University students' income level and their tendency to go and live in the EU countries have a relationship.

$\mathrm{H}_{0} 15$ : University students' region where he/she was born and their perception on EU's image have no relationship.

$\mathrm{H}_{1} 15$ : University students' region where he/she was born and their perception on EU's image have a relationship.

$\mathrm{H}_{0} 16$ : University students' region where he/she was born and their tendency to vote yes in a possible referendum concerning Turkey's EU accession have no relationship. $\mathrm{H}_{1} 16$ : University students' region where he/she was born and their tendency to vote yes in a possible referendum concerning Turkey's EU accession have a relationship.

$\mathrm{H}_{0} 17$ : University students' region where he/she was born and their tendency to go and live in EU countries have no relationship.

$\mathrm{H}_{1}$ 17: University students' region where he/she was born and their tendency to go and live in EU countries have a relationship.

$\mathrm{H}_{0}$ 18: University students' gender and their perception on Turkey's welfare in case of EU membership have no relationship

$\mathrm{H}_{1}$ 18: University students' gender and their perception on Turkey's welfare in case of EU membership have a relationship.

$\mathrm{H}_{0} 19$ : University students' gender and their perception on their own welfare in case of EU membership have no relationship

$\mathrm{H}_{1} 19$ : University students' gender and their perception on their own welfare in case of EU membership have a relationship.

$\mathrm{H}_{0}$ 20: University students' gender and their perception on EU's image have no relationship.

$\mathrm{H}_{1}$ 20: University students' gender and their perception on EU's image have a relationship.

$\mathrm{H}_{0}$ 21: University students' gender and their belief to the Turkey's EU membership have no relationship.

$\mathrm{H}_{1}$ 21: University students' gender and their belief to the Turkey's EU membership have a relationship. 
Table 3: Results of the hypothesis

\begin{tabular}{|c|c|}
\hline HYPOTHESIS & RESULT \\
\hline $\mathrm{H}_{0} 1$ & FAIL TO REJECT / NO RELATIONSHIP BETWEEN VARIABLES \\
\hline $\mathrm{H}_{0} 2$ & FAIL TO REJECT / NO RELATIONSHIP BETWEEN VARIABLES \\
\hline $\mathrm{H}_{0} 3$ & REJECT / RELATIONSHIP BETWEEN VARIABLES \\
\hline $\mathrm{H}_{0} 4$ & FAIL TO REJECT / NO RELATIONSHIP BETWEEN VARIABLES \\
\hline $\mathrm{H}_{0} 5$ & REJECT / RELATIONSHIP BETWEEN VARIABLES \\
\hline $\mathrm{H}_{0} 6$ & REJECT / RELATIONSHIP BETWEEN VARIABLES \\
\hline $\mathrm{H}_{0} 7$ & FAIL TO REJECT / NO RELATIONSHIP BETWEEN VARIABLES \\
\hline $\mathrm{H}_{0} 8$ & FAIL TO REJECT / NO RELATIONSHIP BETWEEN VARIABLES \\
\hline $\mathrm{H}_{0} 9$ & REJECT / RELATIONSHIP BETWEEN VARIABLES \\
\hline $\mathrm{H}_{0} 10$ & REJECT / RELATIONSHIP BETWEEN VARIABLES \\
\hline $\mathrm{H}_{0} 11$ & FAIL TO REJECT / NO RELATIONSHIP BETWEEN VARIABLES \\
\hline $\mathrm{H}_{0} 12$ & FAIL TO REJECT / NO RELATIONSHIP BETWEEN VARIABLES \\
\hline $\mathrm{H}_{0} 13$ & FAIL TO REJECT / NO RELATIONSHIP BETWEEN VARIABLES \\
\hline $\mathrm{H}_{0} 14$ & FAIL TO REJECT / NO RELATIONSHIP BETWEEN VARIABLES \\
\hline $\mathrm{H}_{0} 15$ & REJECT / RELATIONSHIP BETWEEN VARIABLES \\
\hline $\mathrm{H}_{0} 16$ & FAIL TO REJECT / NO RELATIONSHIP BETWEEN VARIABLES \\
\hline $\mathrm{H}_{0} 17$ & FAIL TO REJECT / NO RELATIONSHIP BETWEEN VARIABLES \\
\hline $\mathrm{H}_{0} 18$ & REJECT / RELATIONSHIP BETWEEN VARIABLES \\
\hline $\mathrm{H}_{0} 19$ & REJECT / RELATIONSHIP BETWEEN VARIABLES \\
\hline $\mathrm{H}_{0} 20$ & REJECT / RELATIONSHIP BETWEEN VARIABLES \\
\hline $\mathrm{H}_{0} 21$ & REJECT / RELATIONSHIP BETWEEN VARIABLES \\
\hline
\end{tabular}

\section{Results and Discussions}

This paper tried to analyse young people's specifically university students' expectations from the EU and their perception about EU's image. 
According to main findings of the survey, university students do not have high level of economic expectation from the EU. Previous studies mostly revealed that Turkish public's biggest expectation from the EU is material benefits. Nevertheless, in case of university students in Istanbul, there is an even distribution $(28.87 \%$ agree, $27.63 \%$-neutral, $29.28 \%$-do not agree), when university students are asked regarding the increase in Turkey's welfare in case of EU membership. There are also similar results when they were asked concerning what EU means for them such as welfare and employment. As a result, it can be said that university students do not perceive EU as a source of prosperity predominantly. In the long run, this trend could even decrease more when Turkey gradually increases its prosperity. Nonetheless, when university students are asked about whether they would like to live, study and work in the EU countries a clear majority of university students answered these statements positively. Roughly between $70 \%$ and $80 \%$ of the university students stated that they would like to live and work in EU countries and they would like to study in EU countries respectively.

Why university students do not expect anything from EU countries economically but want to study and work in these countries? Economic crisis in the EU, perception of fast economic growth in Turkey which increased self-confidence can be considered as main reasons behind this, since declining Europe rhetoric is widely used in media and politics. Moreover it can be said that university students tend to look for new experiences to acquire new skills. Another interesting result is that university students' knowledge level is significantly higher than average public. Around $72.16 \%$ and $74.43 \%$ of university students answered questions correctly concerning basic issues about the EU. Nonetheless, only $53.81 \%$ students think they know how EU functions.

When it comes to EU's image, almost half (47.22\%) of the university students perceive EU neutrally. Moreover, $24.95 \%$ of them think that EU membership would be neither good nor bad for Turkey. Even though overall positive perceptions are higher than negative ones, there is strong neutrality among university students concerning EU nowadays.

When compared with other major studies such as Eurobarometer and GMFUS, results are not very different. $48 \%$ and $41 \%$ of the attendants in 2012 thought that EU membership will be a good thing according to GMFUS (2012) and Eurobarometer (2011) respectively while our study found $42.27 \%$. There is significant difference when one compares our study with another study which also has been conducted with university students by Dartan, et al. (2004). \%68 of the students would vote yes in referendum in 2004 while it is $56.08 \%$ today. Furthermore, $46 \%$ perceive EU as a positive thing according to Dartan et al. (2004) while only $30 \%$ see it positive in our study. 
Concerning the hypothesis, one of the most striking result is that income has no relationship with six different variables: university students perception on Turkey's welfare in case of accession, university students own welfare in case of accession, EU image, tendency to vote yes in a possible referendum, tendency to live and work in EU countries and belief in the EU membership. Hence, university students' perception concerning EU issues is independent from their income level.

Region where university students were born has only relationship with their EU image. It has no relationship with university students' perception on Turkey's and their own welfare, tendency to vote yes in a possible referendum and tendency to go and live in EU countries.

Thus, it can be said that university students' perception is mixed due to reasons such as euro crisis, increasing self-confidence of Turkey parallel with opening up to the other countries, Arab Spring and increasing reputation of Turkey in the MENA region, growing mistrust against the $\mathrm{EU}$, mixed signals from political elites to public, stalemate at the relations due to Cyprus issue and some member states governments' relentless objection against Turkey.

\section{Conclusion}

This paper tried to grasp university students' economic expectations from the EU and their perceptions of the EU. Since half of Turkey is under 29 years of age, it is important to analyse youth's opinions.

The survey revealed that economic expectations are not as dominant as before for the university students while they still would like to live, work and study in the EU countries. Moreover, EU's image is quite neutral for university students while mostly they do not believe that Turkey will ever be an EU member. Nonetheless, still majority of them thinks that EU membership is a good thing. Furthermore, there is a significant percentage of attendants which are neutral on EU image, economic expectations etc.

It has been seen that income has no relationship with 6 different variables (university students perception on Turkey's welfare in case of accession, university students their own welfare in case of accession, EU image, tendency to vote yes in a possible referendum, tendency to live and work in EU countries and belief to the EU membership) while region where he/she was born has only relationship with EU's image.

This paper argues that young people specifically university students should be engaged more with the EU affairs. Attendants of this survey will be decisionmakers of the future in Turkey and EU project of Turkey should be spread into grass-root. Since significant percentage of the attendants' are neutral concerning EU issues, their perceptions in the future will be important as well. At the end of the 
day, both Turkish and EU member states' public should be convinced that Turkey's EU accession will be a win-win situation and youth can be an important factor to support this process. 


\section{References:}

Dartan, M., Nas, Ç., Akman, M., Savran, C., \& Suner, S. (2004). Türkiye'nin Avrupa Birliği'ne Katılım Sürecinde Marmara Üniversitesi Öğrencilerinin Geleceğe ve Avrupa ile İlişkilere Bakışı. Marmara Üniversitesi Yayın No. 714, Istanbul

Ekonomi ve Dış Politikalar Araştırma Merkezi (EDAM). (2013), Türkiye'de Dış Politika ve Kamuoyu Anketleri. Public Opinion Survey, Istanbul.

Kadir Has University (2011). Türkiye Sosyal-Siyasal Eğilimler Araştırması 2011. Istanbul.

Kadir Has University (2012). Türkiye Sosyal-Siyasal Eğilimler Araştırması 2012. Istanbul.

Kadir Has University (2013). Türkiye Sosyal-Siyasal Eğilimler Araştırması 2013. Istanbul.

Standard Eurobarometer 54, (2000).

http://ec.europa.eu/public_opinion/archives/eb/eb54/eb54_en.htm (5th December 2012).

Standard Eurobarometer 55, (2001).

http://ec.europa.eu/public_opinion/archives/eb/eb55/eb55_en.htm (5th December 2012).

Standard Eurobarometer 56, (2001).

http://ec.europa.eu/public_opinion/archives/eb/eb56/eb56_en.htm (5th December 2012).

Standard Eurobarometer 57, (2002).

http://ec.europa.eu/public_opinion/archives/eb/eb57/eb57_en.htm (5th December 2012).

Standard Eurobarometer 58, (2002).

http://ec.europa.eu/public_opinion/archives/eb/eb58/eb58_en.htm (5th December 2012).

Standard Eurobarometer 59, (2003).

http://ec.europa.eu/public_opinion/archives/eb/eb59/eb59_en.htm (5th December 2012).

Standard Eurobarometer 60, (2003).

http://ec.europa.eu/public_opinion/archives/eb/eb60/eb60_en.htm (5th December 2012).

Standard Eurobarometer 61, (2004).

http://ec.europa.eu/public_opinion/archives/eb/eb61/eb61_en.htm (5th December 2012).

Standard Eurobarometer 62, (2004).

http://ec.europa.eu/public_opinion/archives/eb/eb62/eb62_en.htm (5th December 2012).

Standard Eurobarometer 63, (2005).

http://ec.europa.eu/public_opinion/archives/eb/eb63/eb63_en.htm (5th December 2012).

Standard Eurobarometer 64, (2005).

http://ec.europa.eu/public_opinion/archives/eb/eb64/eb64_en.htm (5th December 2012).

Standard Eurobarometer 65, (2006).

http://ec.europa.eu/public_opinion/archives/eb/eb65/eb65_en.htm (5th December 2012).

Standard Eurobarometer 66, (2006).

http://ec.europa.eu/public_opinion/archives/eb/eb66/eb66_en.htm (5th December 2012).

Standard Eurobarometer 67, (2007).

http://ec.europa.eu/public_opinion/archives/eb/eb67/eb67_en.htm (5th December 2012).

Standard Eurobarometer 68, (2007).

http://ec.europa.eu/public_opinion/archives/eb/eb68/eb68_en.htm (5th December 2012).

Standard Eurobarometer 69, (2008).

http://ec.europa.eu/public_opinion/archives/eb/eb69/eb69_en.htm (5th December 2012). 
Standard Eurobarometer 70, (2008).

http://ec.europa.eu/public_opinion/archives/eb/eb70/eb70_en.htm (5th December 2012).

Standard Eurobarometer 71, (2009). http://ec.europa.eu/public_opinion/archives/eb/eb71/eb71_en.htm (5th December 2012).

Standard Eurobarometer 72, (2009). http://ec.europa.eu/public_opinion/archives/eb/eb72/eb72_en.htm (5th December 2012).

Standard Eurobarometer 73, (2010). http://ec.europa.eu/public_opinion/archives/eb/eb73/eb73_en.htm (5th December 2012).

Standard Eurobarometer 74, (2010). http://ec.europa.eu/public_opinion/archives/eb/eb74/eb74_en.htm (5th December 2012).

Standard Eurobarometer 75, (2011). http://ec.europa.eu/public_opinion/archives/eb/eb75/eb75_en.htm (5th December 2012).

Standard Eurobarometer 76, (2011). http://ec.europa.eu/public_opinion/archives/eb/eb76/eb76_en.htm (5th December 2012).

The German Marshall Fund of the US, (2004). Transatlantic Trends. http://trends.gmfus.org/files/archived/doc/2004_english_key.pdf (9th December 2012).

The German Marshall Fund of the US, (2005). Transatlantic Trends. http://trends.gmfus.org/files/archived/doc/2005_english_key.pdf (9th December 2012).

The German Marshall Fund of the US, (2006). Transatlantic Trends. http://trends.gmfus.org/files/archived/doc/2006_english_key.pdf (9th December 2012).

The German Marshall Fund of the US, (2007). Transatlantic Trends. http://trends.gmfus.org/files/archived/doc/2007_english_key.pdf (9th December 2012).

The German Marshall Fund of the US, (2008). Transatlantic Trends. http://trends.gmfus.org/files/archived/doc/2008_english_key.pdf (9th December 2012).

The German Marshall Fund of the US, (2009). Transatlantic Trends. http://trends.gmfus.org/files/archived/doc/2009_English_Key.pdf (9th December 2012).

The German Marshall Fund of the US, (2010). Transatlantic Trends. http://trends.gmfus.org/files/archived/doc/2010_English_Key.pdf (9th December 2012).

The German Marshall Fund of the US, (2011). Transatlantic Trends. http://www.gmfus.org/publications_/TT/TT2011_final_web.pdf (9th December 2012).

Triola, M. (2010). Elementary Statistics (11/E b.). Pearson, Boston.

Turkish Social Sciences Association. (2005). Gençlik, AB ve Zıt Hisler: Bedenini İsterim ama Ruhunu Asla. Dipnot Yayınları, Istanbul.

Turkish Statistical Institute. (2011). Istatistiklerle Gençlik. No.3676. Ankara: Turkish Statistical Institute.

Turkish Student Selection and Placement Centre (OSYM). (2012). Yüksekögrretim Istatistikleri, Ankara. 